\title{
A escrita engajada de Pagu contra a opressão de classe social, gênero e raça em Parque Industrial
}

\author{
Pagu engaged writing against social class, gender and race oppression in \\ Industrial Park \\ Francielie MORETTI* \\ Universidade Federal da Integração Latino-Americana (UNILA) \\ Felipe dos Santos MATIAS** \\ Universidade Federal da Integração Latino-Americana (UNILA)
}

\begin{abstract}
RESUMO: O presente artigo apresenta um estudo analítico da obra Parque Industrial (1933), da escritora Patrícia Rehder Galvão (1910-1962), popularmente conhecida como Pagu, dialogando com as considerações teórico-críticas sobre engajamento propostas pelo filósofo francês Jean-Paul Sartre, em Que é a literatura? Pagu faz uma crítica ao in tenso processo de industrialização desumanizadora característico das primeiras décadas do século XX no Brasil, especialmente na cidade de São Paulo, evidenciando o abismo entre os privilégios u sufruídos pela classe dominante e a miséria vivida pelos trabalhadores. A partir da análise realizada, podese dizer que a narrativa de Parque Industrial expõe os dramas vividos pelo proletariado no sistema capitalista, explorado à exaustão. A obra realiza também uma problematização a respeito do feminismo burguês no país, que tendo como principais pautas o sufrágio feminino e o direito das mulheres ao trabalho, mostrava-se alheio à realidade vivenciada pelas proletárias, principalmente em relação ao racismo enfrentado pelas mulheres negras.
\end{abstract}

PALAVRAS-CHAVE: Parque Industrial; Pagu; escrita engajada.

\footnotetext{
* Mestranda em Literatura Comparada na Universidade Federal da Integração Latino-Americana (UNILA). Graduada em História pela Faculdade União das Américas (UNIAMÉRICA). E-mail: francielie.moretti@unila.edu.br

** Doutor em Letras - Estudos Literários pela Universidade Federal de Juiz de Fora (UFJF), com período sanduíche (bolsa CAPES PDSE) na Universidade de Coimbra (UC), Portugal. E-mail: felipe.matias@unila.edu.br
} 
ABSTRACT: This article presents an analytical study of the work Industrial Park (1933), by the writer Patricia Rehder Galvão (1910-1962), popularly known as Pagu, in dialogue with the theoretical-critical considerations about engagement proposed by the French philosopher JeanPaul Sartre, in What Is Literature? Pagu criticizes the intense process of dehumanizing industrialization characteristic of the first decades of the twentieth century in Brazil, espe cially in the city of São Paulo, highlighting the contrast between the privileges enjoyed by ruling-class and the misery experienced by workers. From the analysis carried out, it can be said that the Industrial Park narrative exposes the dramas experienced by the proletariat in the capitalist system, exploited to exhaustion. The work also discusses about bourgeois feminism in the country, whose main agendas are women's suffrage and the right of women to work, showing itself to be alien to the reality experienced by the proletarians, especially in relation to the racism faced by black women.

KEYWORDS: Industrial park; Pagu; engaged writing.

\section{Introdução}

Neste estudo, elaboramos uma proposta de análise da obra Parque Industrial, de Patricia Rehder Galvão (doravante Pagu), enquanto escrita de resistência e engajamento ${ }^{1}$. Durante anos negligenciada pela crítica literária e pela academia, a produção de Pagu passa a ser objeto de estudos sistemáticos somente a partir da década de 1980, com destaque para o livro escrito por Augusto de Campos, Pagu: Vida e obra, publicado originalmente em 1982, e ainda hoje uma importante referência para os estudos sobre a autora; também se destaca a trilogia elaborada pela professora Lucia Maria Teixeira Furlani: Pagu: Patricia Galvão - Livre na imaginação, no espaço e no tempo (1999); Croquis de Pagu - e outros momentos felizes que foram devorados unidos (2004); e Viva Pagu - fotobiografia de Patrícia Galvão (2010), escrito em parceria com o filho mais novo da escritora, Geraldo Galvão Ferraz.

Tendo como cenário a cidade de São Paulo do início da década de 1930, caracterizada pelo acelerado processo de industrialização, Parque Industrial traça um retrato perturbador da exploração a que está submetido o trabalhador no sistema

\footnotetext{
1 Assim como Jean-Paul Sartre, consideramos que "a arte não perde nada com o engajamento; ao contrário"(SARTRE, 2004,p. 23).
} 
capitalista. Mais do que isso, escancara a discrepância entre a miséria da classe operária e os privilégios ostentados pela classe dominante. Para além da influência da perspectiva marxista-leninista ${ }^{2}$, a narrativa construída por Pagu promove reflexões que ultrapassam os limites impostos a uma literatura panfletária, definição comumente atribuída à obra, especialmente quando se pretende justificar os motivos para o silêncio ruidoso acerca de sua existência. Aceitar a ideia de que a obra na realidade é um panfleto comunista, é desconsiderar, inclusive, o fato de que o Partido Comunista Brasileiro $^{3}$ apresentou objeção a sua publicação, obrigando a autora a utilizar um pseudônimo (Mara Lobo), por considerar o referido livro um escândalo ${ }^{4}$. Esta objeção do partido em relação à obra deve ser discutida, visto que é necessário ir além de uma análise superficial e imediatista de seu conteúdo.

Com uma narrativa inspirada pelas renovações estéticas propostas pelo movimento modernista, impulsionado pela Semana de Arte Moderna de 1922, Pagu escreve aquele que é considerado o primeiro romance proletário da literatura brasileira. Contrapondo sua importância e peso histórico, Parque Industrial nunca ocupou lugar de destaque no cânone da literatura nacional ${ }^{5}$, e sua autora tampouco frequentou o panteão de nossas letras. No artigo Parque Industrial: influxos feministas no romance proletário

2 De acordo com Geraldo Galvão Ferraz, “o romance [Parque Industrial] [...] é, contudo, um caso singular no quadro do romance social dos anos 30 , por se fixar na vida proletária de uma grande cidade, usando a perspectiva marxista-leninista para fustigar os aspectos dolorosos do desenvolvimento industrial" (FERRAZ apud GALVÃO, 2006,p. 9-10).

3 Segundo Anselmo Peres Alós, "Pagu ingressa no Partido Comunista em 1931 e, em 23 de agosto do mesmo ano, é presa como agitadora, em Santos (no Estado de São Paulo), por participar de um comício na Praça da República em homenagem a Sacco e Vanzetti, por ocasião de uma greve de estivadores. Expoente de grau máximo da luta social de sua época, Pagu foi a primeira mulher brasileira a se tornar presa política" (ALÓS, 2010,p. 187).

${ }^{4}$ Nessa direção, o filho de Patrícia Galvão afirma que "o romance proletário Parque Industrial não deixou de contribuir para a lenda. Ela [Pagu] o terminou em 1932, publicou-o em 1933. Com um pseudônimo, por causa do Partido [Comunista Brasileiro]. Um escândalo! Como alguém poderia dizer tantas verdades por linha, denunciando a vida dos humilhados e ofendidos pela sociedade paulistana? Como alguém poderia mostrar a desigualdade inata das classes no sistema capitalista? Como alguém poderia ousar tanto, numa sociedade moralmente hipócrita, mostrando que ha via perversões e corru pçã o, não se furtando às cenas sexualmente explícitas? A propósito, isso deve ter desagradado também os comunistas, em estado de policia mento moralizante. Como alguém se atrevia a esta mpar a linguagem da s ruas? Finalmente, como alguém podia querer exaltar daquela forma a condição feminina?" (FERRAZ apud GALVÃO, 2006, p. 8).

5 Para Glauce Souza Santos, "o estudo de Parque Industrial [...] é um gesto que contribui com a visibilidade da escritora, permitindo questionamentos, comparações e identificações a respeito da sua escrita ousada e de denúncia da vida dos humilhados e ofendidos da sociedade paulistana. Nessa narrativa, há cenas sexuais explícitas, como também linguagem das ruas e a exaltação da condição feminina. Sua concentração é nas mulheres operárias e militantes. Por isso, nessa obra, Pagu detém -se no comportamento do proletariado urbano feminino e critica veementemente a sociedade burguesa, de um ângulo socialista, denunciando a exploração da mulher operária e apontando os privilégios e hipocrisias da classe burguesa de São Paulo" (SANTOS, 2017,p. 199).

Revista Moara, n. 59, ago-dez 2021 ISSN: 0104-0944 
de Patricia Galvão, Anselmo Peres Alós argumenta que "o fato de Pagu ter disseminado sua atuação em tantas áreas distintas da vida cultural (o jornalismo, a militância política, a literatura e o desenho, entre tantas outras)" (ALÓS, 2010, p. 186) pode ter sido determinante para que não tivesse sua produção literária reconhecida e valorizada. Entretanto, nessa reflexão acerca dos motivos que levaram ao apagamento da escritora na historiografia da literatura brasileira, não podemos minorar o fato de que Pagu era uma mulher escrevendo na década de 1930, e utilizando-se de uma linguagem subversiva, tanto no conteúdo quanto na forma estética de seu texto. Além disso, sua destacada militância política, sempre contrária aos interesses do poder hegemônico, também pode ter sido fator decisivo para que a autora fosse,deliberada e convenientemente, "deixada de fora" do cânone literário nacional.

Assim, nesse artigo buscaremos, inicialmente, refletir sobre os caminhos percorridos por Pagu, desde sua aproximação com os intelectuais do modernismo antropofágico (influência marcadamente presente na escrita de Parque Industrial), e a posterior adesão ao Partido Comunista Brasileiro, fato que vai ser determinante em sua trajetória. Num segundo momento, a análise se debruçará sobre a escrita de Parque Industrial, a partir de sua compreensão enquanto literatura engajada e de resistência, uma vez que se levanta contra a lógica de exploração imposta pela ótica do capital, e instiga a reflexão acerca das injustiças sociais que caracterizam as sociedades sob o jugo do sistema capitalista. Por fim, na última parte desse artigo, analisaremos a problematização feita por Pagu na referida obra ao feminismo burguês. O tom de crítica pode ser percebido na construção das cenas em que se faz referência às feministas, geralmente apresentadas como alheias à realidade da maioria das mulheres do Brasil da década de 1930.

\section{1 "Mulher de ferro com zonas erógenas e aparelho digestivo"}

Pagu foi uma escritora que, em geral, teve sua produção negligenciada pela crítica. É comum nos escritos sobre ela, encontrarmos argumentos que definem sua militância política como o aspecto mais importante de sua trajetória de vida, relegando à sua produção literária papel menor. É sintomático que mesmo na apresentação escrita por seu filho, Geraldo Galvão Ferraz, para a edição de Parque Industrial feita pela 
editora José Olympio, ele reitere o argumento de que o romance seria "de valor estético absolutamente desigual, prejudicado pelo panfletarismo e, talvez, pela inexperiência vivencial da jovem de 21 anos que o escreveu" (FERRAZ apud GALVÃO, 2006, p. 9). Esse é o entendimento que durante muito tempo pautou o imaginário sobre a literatura produzida por Pagu, sempre encoberto pela ideia estereotipada de militante política e amante/esposa de Oswald de Andrade (a responsável pela separação dele de Tarsila do Amaral), negligenciando, sobretudo, sua profícua produção, que abrange romances, poemas, desenhos, tirinhas e artigos publicados em periódicos.

Nascida em uma família de classe média do interior paulista, Pagu muda-se, ainda adolescente, para o bairro do Brás, região característica por ser reduto do operariado paulistano e por abrigar as fábricas que compõem o incipiente panorama industrial de São Paulo. Esse é o cenário em que grande parte das cenas de Parque Industrial se desenvolvem. Data desta época, a primeira contribuição da escritora para um jornal, aos quinze anos de idade, quando Pagu escreve para um veículo de comunicação do bairro onde morava, o Brás Jornal ${ }^{6}$, utilizando seu primeiro pseudônimo, Patsy. Ao longo de sua carreira, vai ser comum a utilização de pseudônimos na assinatura de seus trabalhos, sendo os mais comuns: Pagu, Zazá, Gim, Solange Sohl, Mara Lobo, Irmã Paula, G., Léa, K.B.Luda, Peste, King Shelter, Cobra, Ariel, Pat, Pt e Leonie. A utilização desses pseudônimos reflete motivações políticas, uma vez que, devido às perseguições dos "órgãos de segurança" do governo Getúlio $\operatorname{Vargas}^{7}$, passou grande parte dos anos de militância na clandestinidade.

Deve-se a isso também a dificuldade em reunir todos os escritos da autora, embora várias tentativas já tenham sido realizadas nesse sentido, mas o fato é que ainda não se sabe o quanto de Pagu resta por descobrir. Exemplo disso são os contos policiais da autora. Seu filho, Geraldo, encontrou em uma livraria de São Paulo, por acaso, uma

\footnotetext{
${ }^{6}$ Nesse sentido, Anselmo Peres Alós diz que "aos 15, em 1925, [Pagu] trabalha no Brás Jornal, sob o pseudônimo de Patsy" (ALÓS, 2010,186).

7 De acordo com Araújo, Silva e Priori, "durante o Governo de Getúlio Vargas, foi promulgada a Constituição de 1934 e, em 1937, houve o fechamento do Congresso Nacional e a instalação do Estado Novo, o qual revelava um governo ditatorial, centralizador e controlador. Criou -se o DIP (Departamento de Imprensa e Propaganda) para controlare censurar manifestações contrárias a esse governo, haven do a perseguição dos opositores políticos, principalmente partidários do Comunismo" (ARAÚJO, SILVA e PRIORI, 2014, p. 7).
} 
coletânea de escritos dela em edições da revista Detective $^{8}$, famosa nos anos 30 e 40 por reunir contos policiais. Nessas revistas, Geraldo descobriu alguns contos assinados por King Shelter, pseudônimo que ele conhecia de correspondências trocadas entre seus pais. Foi desse encontro casual que resultou o livro Safra Macabra, publicado na década de 1990, e que reúne os contos policiais escritos por Pagu e publicados, originalmente, na revista Detective. Quando esteve na prisão por motivos políticos (entre os anos de 1935 a 1940), ela escreveu o que seria a segunda parte de uma obra intitulada Microcosmo. Pagu e o homem subterrâneo - 1939. Correspondência, que reúne textos poéticos autobiográficos. Essa seria a segunda parte de um romance, cuja primeira parte fora enterrada em um terreno de São Paulo, na tentativa de preservá-lo, devido ao fato de que Pagu estava sendo perseguida pela polícia em decorrência de suas atividades políticas ligadas ao comunismo. Após deixar a prisão, tentou recuperar esses escritos, o que já não foi mais possível, pois um edifício havia sido construído sobre o terreno utilizado como esconderijo (FERRAZ; FURLANI, 2010, p. 182-183).

É comum a imagem de Pagu ser associada ao movimento modernista. A aproximação com os intelectuais modernistas ocorreu quando ela ainda era uma colegial, ao conhecer o poeta Raul Bopp, responsável por apresentá-la ao casal Oswald de Andrade e Tarsila do Amaral. É Bopp também o responsável pela alcunha com a qual ficará nacionalmente conhecida. Por acreditar que seu nome era Patrícia Goulart, o poeta passou a chamá-la Pagu, pseudônimo popularizado em seu poema Coco de Pagu, escrito em 1928. A partir desse momento, a jovem artista começou a frequentar os saraus e encontros da intelectualidade modernista de São Paulo, festejada como uma espécie de "musa antropofágica". Nas palavras do pintor modernista Flavio de Carvalho, em depoimento para o jornal O Estado de São Paulo, Pagu "era uma colegial que Tarsila e Oswald resolveram transformar em boneca. Vestiam-na, calçavam-na, penteavam-na, até que se tornasse uma santa flutuando sobre as nuvens" (CARVALHO apud CAMPOS, 2014, p. 244).

O relacionamento amoroso com Oswald vai demarcar o término de sua relação com boa parte da intelectualidade modernista. Os dois passam a ser uma espécie de persona non grata nas rodas da elite paulista, aturdidas pelo escândalo da separação do

\footnotetext{
${ }^{8}$ Lançada em 1936, pelo grupo Assis Chateaubriand, a revista Detective foi dirigida pelo jornalista e escritor Nelson Rodrigues (1912-1980). O magazine publicava histórias de crimes, guerras, velho oeste e ficção científica.
} 
casal sensação do modernismo brasileiro, e no qual, considerando as estruturas sociais machistas e patriarcais, obviamente, cabia à Pagu o papel de responsável pela destruição do lar de Tarsila. Esse rompimento será decisivo também para que Pagu aproxime-se da militância política, já que a elite artística, em sua maioria composta pela classe social dominante, não era vista com bons olhos pelo Partido Comunista, que entra na vida de Pagu após viagem realizada à Argentina para participar de um recital. Nesta viagem, a escritora conhece Jorge Luis Borges, Eduardo Mallea, Norah Borges e Victoria Ocampo. Suas impressões sobre o encontro foram registradas na carta que escreve para seu marido, Geraldo Ferraz, quando ela ainda estava na prisão, e que posteriormente seria publicada no livro autobiográfico Paixão Pagu (2005). O excerto a seguir ilustra o que foi dito:

\footnotetext{
Aquelas assembleias literárias, como eram enfadonhas. $\mathrm{O}$ ambiente idêntico ao que conhecia cercando os intelectuais modernistas do Brasil. As mesmas polemicazinhas chochas, a mesma imposição da inteligência, as mesmas comédias sexuais, o mesmo prefácio exibicionista para tudo. Victoria Ocampo, pessoalmente, ficou uma velha harpia, espiando, atropelando e encabrestando Mallea, o seu menino de ouro. Megera obscena. Depois das sua s preleções íntimas, não mais consegui ligá-la à colaboradora da Revista de Occidente. Norah, que julguei mais interessante apesar da sua pintura convencional, era apenas uma crítica de modas. Borges quis se despir no meu quarto cinco minutos depois de me conhecer. Fazer lutinha comigo. Gente sórdida. Mas eu bem que vivia no meio deles. [...] Mas deram-me impressão de revolucionarismo convencionado à depravação, que não passavam de gente embolorada, cercada por estatutos de um conventículo convenciona damente exótico (GALVÃO, 2005,p. 72-73).
}

A opinião de Pagu evidencia que mesmo antes de sua aproximação à causa comunista, o sentimento a respeito dos artistas modernistas era de frustração e reprovação em relação ao que considerava como superficialidade e frivolidade das ações deles. Nessa mesma viagem, ela vai ter um encontro com Silo Meirelles, importante nome da Liga de Ação Revolucionária, o qual a incumbe de trazer para o Brasil alguns materiais de divulgação e livros da causa, que teriam como destino os líderes comunistas brasileiros. Assim, ao retornar ao país, a casa de Oswald e Pagu passa a ser ponto de encontro dos militantes comunistas, incluindo visitas constantes de 
Astrogildo Pereira, um dos fundadores do Partido Comunista Brasileiro, e presidente da agremiação na época. O processo de formação política de Pagu estava iniciado. É neste contexto que surge, em 1931, o jornal O Homem do Povo, em que, influenciados pela doutrina marxista, Pagu e Oswald dedicam-se à escrita de críticas à sociedade capitalista da época. No que concerne à adesão do casal às ideias marxistas, Tereza Freire faz a seguinte afirmação:

\footnotetext{
Esse primeiro contato de Pagu com o comunismo é principalmente intelectual. Com a tradução dos textos, passa a estudar a literatura marxista trazida da Argentina, no que é acompanhada por Oswald. A vida do casal ganha um novo sentido. Era preciso se proletarizar. A luta de classes deveria ocuparo lugar das festas e das roupas caras. Para isso, deveriam ser coerentes e viver como proletários se quisessem ser aceitos como membros do Partido Comunista (FREIRE, 2008, p. 64).
}

Em 1931, Pagu viaja para Montevidéu com Oswald, após as confusões com os estudantes da Faculdade de Direito do Largo de São Francisco, que a partir de um artigo de Oswald - publicado no Homem do Povo, em que havia classificado a instituição como um "cancro que mina a existência e patrimônio do nosso Estado" - foram até a sede do periódico confrontar seus redatores. Durante a confusão, dois tiros são disparados e Pagu é acusada de ter sido a responsável pelos disparos. Essa acusação agrava ainda mais a situação do jornal, e o delegado de polícia determina a suspensão definitiva da publicação do periódico. Esse é o cenário que levou Pagu e Oswald a embarcarem para o Uruguai. Nessa viagem, Pagu tem um encontro com Luís Carlos Prestes, determinante para seu ingresso no Partido Comunista:

\footnotetext{
Fomos um pouco a passeio, um pouco para fugir das complicações do processo que moviam pelos ferimentos que me atribuíam contra os estudantes que quiseram empastelar o jornal. No dia seguinte à nossa chegada, fomos procurados por um homem de aparência medíocre. Eu estava só e quase despedi o nosso visitante, que era Luís Carlos Prestes. Conversamos três dias e três noites, num cafezinho fechado e deserto. Consumimos, penso que, quilos de café. Não dormíamos e consegui saber que o comunismo era coisa séria. E fiquei conhecendo a grandiosidade de uma coisa até então desconhecida para mim - o espírito de sacrifício. Prestes mostrou-me
} 
concretamente a abnegação, a pureza de convicção. Fez-me ciente da verdade revolucionária e acenou-me com a fé nova. [...] Disso acenou-me, apenas, porque a fé, em toda a sua extensão, só mais tarde tomou conta absoluta de minha pessoa (GALVÃO, 2005,p. 75).

A partir de seu ingresso no PCB, sua relação com Oswald e Rudá de Andrade (seu primeiro filho) é entrecortada por longos períodos de afastamento, em que Pagu passava desenvolvendo atividades para o partido. Mas mesmo antes do início de suas atividades políticas, Pagu já se mostrava insatisfeita com as condições impostas pela maternidade. A viagem para participar de um recital na Argentina ocorreu quando Rudá tinha três meses, e ao descrever seus sentimentos quanto a esse fato, ela fez a seguinte confissão:

Partindo, deixei o alvorecer dos primeiros sorrisos e não pude acompanharos sintomas que se gravam no olhar da primeira compreensão humana. Deixei tudo isso, sem querer confessar que o meu interesse materno era menor que meu desejo de fuga e expansão (GALVÃO, 2005, p. 69).

A relação de Pagu com o Partido Comunista Brasileiro foi conflituosa. Desde sua entrada, em 1931, até sua expulsão, em 1939, o estigma de "burguesa inconsequente" e "degenerada sexual" acompanhou sua trajetória na agremiação. Em 1931, ao ser detida9 ${ }^{9}$ durante um comício comunista em Santos, no qual o estivador Herculano de Souza foi assassinado pela polícia, teve a primeira mostra dos termos que pautariam sua relação com o partido. Ao deixar a prisão, o PCB a fez assinar uma declaração em que assumia ter agido sem autorização dos colegas partidários. Essa exigência devia-se ao fato de que o nome de Pagu ganhara notoriedade após o episódio, e as normativas do partido exigiam que nenhum integrante fosse mais importante do que o próprio $\mathrm{PCB}$, especialmente se esse nome era de uma recém ingressa de origem "pequeno burguesa". Pagu é considerada a primeira presa por motivos políticos no Brasil. Durante a vida foi presa 23 vezes, todas elas por razões políticas. Em 1939, foi

\footnotetext{
9 “Após sua primeira prisão, sucederam diversos a contecimentos que marcariam a vida de Pa trícia Galvão no decênio de 1930: a mudança para o Rio de Ja neiro em 1932 e, no ano seguinte, publica a obra Parque Industrial [...]; viaja pelo mundo em 1934, e nos meses em que morou em Paris (sem Oswald e o filho) foi presa como militante comunista estrangeira. Regressou ao Brasil apenas em 1934 e, por duas vezes, em 1935 e 1938, seria presa novamente. Fora libertada em julho de 1940, depauperada e magérrima" (ARAÚJO, SILVA e PRIORI, 2014,p. 21).
} 
expulsa do Partido Comunista Brasileiro, que, em panfleto do Comitê Regional de São Paulo, publica a seguinte nota:

\author{
OS QUE SÃO EXPULSOS AGORA: PATRICIA GALVÃO \\ Conhecida geralmente com o nome de PAGU. Desde princípios de 1937 que \\ não mais pertencia a o Partido. Muito conhecida pelas atitudes escandalosas \\ de degenerada sexual. Depois que "fugiu" do Hospital da Cruz Azul, onde se \\ encontrava presa, ligou-se a grupo fracionista-trotskista, onde pa ssou a atuar \\ ativamente, tendo sido enviada pa ra o Rio de Janeiro, com a incumbên cia de \\ formaro CR trotskista (FURLANI; FERRAZ, 2010,p. 185).
}

Parque Industrial é resultado da relação de devoção junto ao PCB. A obra foi escrita num momento em que Pagu ainda nutria grande admiração pela sigla partidária. Porém, a escritora transpõe os limites do que seria uma discussão apropriada para os termos do partido, e toca em assuntos que não agradam ao Partido Comunista Brasileiro. Na obra, Pagu contesta, por exemplo, a moral sexual imposta. Assim, o potencial subversivo de sua escrita está expresso não somente nas discussões acerca da luta de classes, que caracterizam o embate entre a classe dominante e o proletariado, mas também no recorte de gênero e raça proposto pela escritora. Com isso, a situação da mulher e as múltiplas violências sofridas aparecem de modo recorrente na obra, o que pode ter contribuíd o para que o livro não fosse objeto festejado no partido comunista.

No período em que escreveu o texto literário, ela tinha convicção quanto à importância dos ideais comunistas. Entretanto, Pagu não se sujeita à escrita obediente aos preceitos do partido, a subversão presente em sua escrita é um reflexo de sua postura perante o mundo. Discutir pautas que problematizassem a condição da mulher na sociedade capitalista não era algo que o partido comunista priorizasse, ou mesmo, considerasse importante. Pagu faz isso e, de forma escancarada, revela as opressões sofridas pelas mulheres, principalmente em relação às mais pobres.

A historiadora Mary Del Priore, ao discutir a questão da contracepção no Brasil, vai dizer que durante o Estado Novo de Vargas, existia um forte apelo quanto à importância da coesão social, como elemento determinante para a o fortalecimento da ideia de pátria. Neste sentido, era fundamental a definição de um modelo de família que expurgaria todas as ameaças à ordem - imoralidade, sensualidade e indolência -, e para 
que esse modelo se concretizasse, "o papel da mulher não era na rua, trabalhando, mas em casa, cuidando dos filhos. E de todos" (DEL PRIORE, 2011, p. 144-145). Pagu não se encaixou nesse parâmetro, visto que não desempenhou o papel de mãe e esposa conforme preconizados pela moral da época. Era, conforme sua própria autodefinição elaborada em carta ao marido Geraldo Ferraz, uma "mulher de ferro, com zonas erógenas e aparelho digestivo" (GALVÃO, 2005, p. 70).

\section{2 "Militante do ideal": a escrita de Parque Industrial}

A escrita de Parque Industrial é marcada pela experimentação estética. Por ser simpatizante das experimentações formais do grupo modernista de 22, Pagu utiliza uma linguagem fragmentada, repleta de flashes na estruturação da narrativa e de um vocabulário coloquial que "apresenta elementos da linguagem diária, cotidiana, considerada grosseira" (ALÓS, 2010, p. 191). A escolha por esse estilo de escrita literária pode ter contribuído para chocar a audiência da época, incluindo o Partido Comunista, inicialmente o principal destinatário da obra. Outra importante característica dessa obra de Pagu é que o protagonismo pertence à coletividade, à massa, ao proletariado. Assim, embora alguns personagens possuam uma história contada ao longo dos capítulos, é comum na narrativa o aparecimento de personagens que se limitam apenas a uma cena e que, em sua maioria, não tenham nome.

Dentre os personagens que possuem um enredo, o pesquisador João Carlos Ribeiro Junior (2015) propõe a seguinte classificação:

\footnotetext{
Há três grupos principais: os trabalhadores conscientes, que dedicam a vida à construção partidária e estão engaja dos na causa da revolução; trabalhadores inconscientes, preocupados, sobretudo, com o matrimônio, seja para chegar à burguesia seja para acomodar-se em vida familiar; e por fim os burgueses, em sua grande maioria expostos em imagem amoral e condenável do ponto de vista ético (RIBEIRO JUNIOR, 2015, p. 31).
}

A autora faz uso de prosopopeias para evidenciar o processo de coisificação sofrido pelo ser humano, sufocado pela ação das máquinas no sistema industrial. Evidencia-se, também, o viés pedagógico da obra, pois havia o interesse de que o livro 
alcançasse o proletariado, que fosse lido pela classe trabalhadora, aquela que seria responsável por fazer a revolução. Nesse sentido, a composição gráfica da primeira edição do livro trazia especificidades como "tipologia grande em páginas de generosos espaços em branco", o que "faz crer que o livro foi pensado para um leitor pouco treinado, por isso deveria ser mais convidativo" (RIBEIRO JUNIOR, 2015, p. 19). Há uma cena, no segundo capítulo da obra, que exemplifica o viés didático utilizado pela autora:

Rosinha Lituana explica o mecanismo da exploração capitalista.

- O dono da fábrica rouba de cada operário o maior pedaço do dia de trabalho. É assim, que enriquece à nossa custa!

- Quem foi que te disse isso?

- Você não enxerga? Não vê os automóveis dos que não trabalham e a nossa miséria?

- Você quer que eu arrebente o a utomóveldele?

- Se você fizer isso sozinho, irá para a cadeia e o patrão continuará passeando noutro automóvel. Mas felizmente existe um partido, o partido dos trabalhadores, que é quem dirige a luta para fazer a revolução social.

- Os tenentes?

- Não. Os tenentes são fa scistas.

- Então o quê?

- O Partido Comunista...

Novamente as ruas se tingem de cores proletárias. É a saída da Fábrica (GALVÃO, 2006, p. 21-22).

Nesse fragmento, a personagem Rosinha Lituana, uma clara referência à militante marxista Rosa Luxemburgo, explica aos operários como acontece a exploração dos trabalhadores no sistema capitalista. Numa linguagem direta e acessível, aborda conceitos complexos, como o de "mais-valia", a partir da realidade vivida pelo operariado. Sua fala explicita também a importância da organização dos trabalhadores que individualmente possuem pouco poder de ação, mas que organizados podem fazer a revolução. Rosinha Lituana esclarece ainda que essa organização deve ser orquestrada pelo Partido Comunista, e que o partido dos tenentes era fascista, numa clara alusão aos membros da Ação Integralista Brasileira (AIB). No filme O Homem do Pau-Brasil, com roteiro baseado na obra de Oswald de Andrade, o cineasta Joaquim Pedro de Andrade 
realiza uma releitura interessante de algumas cenas de Parque Industrial, e retrata Pagu como Rosinha Lituana, a defensora das ideias marxistas, que mantém no mencionado filme um romance com Oswald de Andrade.

Pagu almejava que seu livro agradasse ao Partido Comunista, uma vez que, acompanhando as orientações vindas do Kremlin, o partido passava por um processo de depuração dos intelectuais, com a orientação expressa de que eles se proletarizassem. Embora dedicados à causa socialista, Pagu e Oswald ainda eram vistos como intelectuais elitistas. No ano que antecedeu à publicação do livro, ocorrida em 1933, Pagu, após deixar Oswald e o filho Rudá em São Paulo, desenvolveu no Rio de Janeiro, por orientação do Partido Comunista, várias atividades profissionais consideradas "proletárias", atuando como costureira, copeira, metalúrgica e lanterninha de cinema. Em uma dessas atividades, acaba se ferindo, e é orientada pelo partido a regressar à vida matrimonial com Oswald, uma vez que o PCB não poderia ajudá-la. Pagu, então, retorna a São Paulo, e vê na publicação do livro uma possibilidade de manter os laços com o partido, já que, ferida, não poderia trabalhar em atividades consideradas, pelos membros da sigla partidária, como dignas de uma proletária. Enquanto esteve no Rio de Janeiro, membros do PCB haviam proibido Pagu de realizar trabalhos por eles considerados intelectualizados, como, por exemplo, escrever.

Por exigência do partido, publica a obra Parque Industrial com um pseudônimo, Mara Lobo. Entretanto, seu intento inicial, de escrever um livro que agradasse ao partido, não logrou êxito, visto que sua escrita transgressora não foi bem vista pelo PCB do início da década de 1930. Essa atitude de transgressão é um dos motivos que nos faz questionar a classificação da obra como panfleto comunista, pois a definição, além de não refletir toda a complexidade presente no livro, não repercute a rejeição que a obra teve dentro do próprio Partido Comunista. Pagu demonstra com seu texto literário uma profunda sensibilidade acerca das questões sociais que se apresentavam na época. Nesse sentido, consideramos que em Parque Industrial ela se constitui como uma escritora engajada com o seu tempo, conforme definição proposta por Jean-Paul Sartre, em Que é a literatura?:

O escritor "engajado" sabe que a pa la vra é ação: sabe que desvendaré muda r e que não se pode desvendar senão tencionando mudar. Ele abandonou o 
sonho impossível de fazeruma pintura imparcialda sociedade e da condição humana (SARTRE, 2004, p. 20-21).

Para além de tentar realizar uma ingênua e falaciosa "pintura imparcial" da realidade vivida, Pagu demonstra em sua narrativa estar comprometida com a sociedade na qual estava inserida. Giorgio Agamben, em $O$ que é contemporâneo e outros ensaios, defende que "aqueles que coincidem muito plenamente com a época, que em todos os aspectos a esta aderem perfeitamente, não são contemporâneos porque, exatamente por isto não conseguem vê-la, não podem manter fixo o olhar sobre ela" (AGAMBEN, 2009, p. 59). Para o filósofo italiano, “contemporâneo é aquele que mantém fixo o olhar no seu tempo, para nele perceber não as luzes, mas o escuro" (AGAMBEN, 2009, p. 62). Pagu pareceu ter compreendido as sombras e a obscuridade de seu tempo, pois tentou narrar em sua obra o horror social que estava vivenciando. Dessa forma, pode-se dizer que ela estava sintonizada com o papel do escritor engajado, que Sartre define como:

O papel do escritor está definido: enquanto negatividade, a literatura contestará a a lienação do trabalho (marxismo); enquanto criação e superação a presentará o homem como ação cria dora e o a companhará em seus esforços para superar a alienação presente, rumo a uma situação melhor. [...] Os escritores foram levados pelas circunstâncias a examinar as relações entre o ser e o fazer, segundo a perspectiva de nossa situação histórica. Somos aquilo que fazemos? O que fazemos a nós mesmos? E ocorre isso na sociedade atual, em que o trabalho é alienado? Que fazer, que finalidade escolher, hoje? E como fazer, por quais meios? Quais são as relações entre o fim e os meios numa sociedade baseada na violência? As obras inspiradas em tais preocupações não podem aspirar primeiramente a agradar: elas irritam e inquietam, colocam-se como tarefas a cumprir, convidam a buscas sem conclusão, mostram experiências cujo resulta do é incerto (SARTRE, 2004, p. 173-174).

Para Sartre, um escritor "é engajado quando trata de tomar a mais lúcida e integral consciência de ter embarcado, isto é, quando faz o engajamento passar, para si e para os outros, da espontaneidade imediata ao plano refletido. $\mathrm{O}$ escritor é mediador por excelência, e o seu engajamento é a mediação" (SARTRE, 2004, p. 61-62). Nessa 
direção, pode-se asseverar que Pagu, por meio de sua escrita engajada e do processo de mediação, buscou conscientizar o proletariado acerca das injustiças de um sistema que massacra o trabalhador, e que é ainda mais perverso com as mulheres ${ }^{10}$, exploradas em sua condição proletária e subjugadas em sua condição de gênero. De forma pungente, a escritora tentou revelar os mecanismos da opressão de classe e instigar a reflexão acerca das arbitrariedades que alimentam a estrutura de desigualdades sociais, ambicionando fazer, por meio de seu texto literário, "com que ninguém possa ignorar o mundo e considerar-se inocente diante dele" (SARTRE, 2004, p. 21). Assim, no primeiro capítulo de Parque Industrial, após um texto introdutório intitulado "Da estatística industrial do estado de São Paulo" - no qual são apresentados números, dos anos 20 ao início da década de 30 do século XX, referentes à produção industrial do referido ente da federação brasileira -, têm-se a seguinte assertiva, escrita em letras maiúsculas:

A ESTATÍSTICA E A HISTÓRIA DA CAMADA HUMANA QUE SUSTENTA O PARQUE INDUSTRIAL DE SÃO PAULO E FALA A LÍNGUA DESTE LIVRO ENCONTRAM-SE, SOB O REGIME CAPITALISTA, NAS CADEIAS E NOS CORTIÇOS, NOS HOSPITAIS E NOS NECROTÉRIOS (GALVÃO, 2006,p. 16).

Já nesse início, evidencia-se o posicionamento político presente na obra. Desse modo, o livro "fala a língua" dos proletários, que são os responsáveis por sustentar o parque industrial, e que estão submetidos às violações impostas pelo regime capitalista. Ao demarcar essa diferença, a discursividade ganha contornos de resistência. Em Literatura e resistência (2002), Alfredo Bosi define que "resistência é um conceito originariamente ético, e não estético. O seu sentido mais profundo apela para a força da vontade que resiste a outra força, exterior ao sujeito" (BOSI, 2002, p. 118). Para Bosi, a ética pode levar ao ato de resistência do artista por meio de sua obra. Assim, podemos dizer que a narrativa construída por Pagu configura-se como uma estratégia de resistência ética e estética que realiza uma denúncia em relação às arbitrariedades sóciohistóricas percebidas. Desse modo, percebe-se, mais uma vez, o engajamento da autora.

\footnotetext{
10 De acordo com Glauce Souza Santos, "com o acesso ao trabalho nas fábricas, a mulher passou a ser explorada de diversas maneiras: falta de respeito, carga horária de trabalho exacerbada e ainda pela exploração sexualdos que ocupa vam posições superiores. Em sua narrativa, Pagu mostra que as mulheres passaram a ocupar o mesmo espaço ocupado pelos homens diante das mesmas máquinas, ritmos e exigências que ornamentam o universo fabril” (SANTOS, 2017,p. 202).
}

Revista Moara, n. 59, ago-dez 2021 ISSN: 0104-0944 
Alguns pesquisadores dedicaram-se a pensar os motivos pelos quais Parque Industrial, mesmo sendo considerado o primeiro romance proletário ${ }^{11}$ brasileiro, não tenha entrado para o cânone nacional. Nessa direção, algumas constatações a respeito disso parecem bastante óbvias, como o fato de que na década de 1930 o campo literário era ainda bastante hostil no que concerne à autoria feminina. Não que hoje essa realidade esteja satisfatoriamente superada, mas há décadas atrás era muito mais difícil ser uma mulher escritora, em comparação com a atualidade. Assim, para além do conteúdo apresentado, a própria escrita do livro torna-se sinônimo de resistência e engajamento. O processo de estigmatização pelo qual Pagu passou, contribuiu para que sua escrita não fosse devidamente reconhecida. Sua escrita em Parque Industrial provoca problematizações que podem ter contribuído para o silêncio acerca da obra. Em um cenário literário bastante elitizado, ela iria, por exemplo, retratar uma intelectualidade que desconhece a complexidade da realidade social do país em que vive, alheia à brutalidade a que estão submetidos os trabalhadores no sistema capitalista, conforme se observa no trecho a seguir:

Bruna está com sono. Estivera num baile até tarde. Para e aperta com raiva os olhos ardentes. Abre a boca cariada, boceja. Os cabelos toscos estão polvilhados de seda.

- Puxa! Que esse domingo não durou... Os ricos podem dormir à vontade.

- Bruna, você se machuca. Olha as tranças!

É o seu companheiro, perto.

O chefe da oficina se a proxima, vaga roso, carrancudo.

- Eu já falei que não quero prosa aqui!

- Ela podia se machucar...

- Malandros!É por isso que o trabalho não rende. Sua vagabunda!

Bruna desperta. A moça abaixa a cabeça revoltada.É preciso calara boca!

Assim, em todos os setores proletários, todos os dias, todas as semanas, todos os anos!

Nos sa lões dos ricos, os poetas lacaios declamam:

- Como é lindo o teu tear! (GALVÃO, 2006,p. 19)

${ }^{11}$ Para Juliana Borges Rodrigues, "o objetivo principal desse tipo de literatura era o de concretizar um projeto de literatura engajada na revolução, o que garantiria não apenas mais um romance de formato burguês" (RODRIGUES, 2009, p. 54). 
O texto de Parque Industrial evidencia a crítica de Pagu em relação à classe dominante, aos intelectuais relacionados com a elite social, e às feministas burguesas. Desse modo, pode-se dizer que sua obra procura romper com o status quo, com o papel social que uma mulher deveria ocupar segundo a lógica imposta pela sociedade patriarcal. O Brasil do início da década de 1930, especialmente a São Paulo onde Pagu vivia, estava passando por um acelerado processo de industrialização. Sensível ao seu tempo, ela consegue captar a dissonância entre a riqueza usufruída pela elite e a miséria e exploração que caracterizam a vida dos trabalhadores, em um período marcado pela polarização política e ascensão de regimes totalitários. Desse modo, pode-se dizer, a partir das reflexões de Agamben, que Pagu é uma voz representativa de sua época ${ }^{12}$, visto que "contemporâneo é, justamente, aquele que sabe ver essa obscuridade, que é capaz de escrever mergulhando a pena nas trevas do presente [...] quem não se deixa cegar pelas luzes do século e consegue entrever nessas a parte da sombra" (AGAMBEN, 2009, p. 63-64).

\section{3 "Ignorantes da vida e do nosso tempo": A crítica ao feminismo burguês}

Num momento em que as feministas brasileiras estavam ainda comemorando a conquista do voto feminino, reconhecido a partir do código eleitoral promulgado pelo governo provisório em 1932, Pagu manifestava sua recusa em compreender as pautas do feminismo burguês como representativas de todo o gênero feminino. Embora tivesse sido estendido às "mulheres", o direito ao voto continuava proibido para as/os analfabetas/os, condição que acometia muitas mulheres da classe trabalhadora. É esse tipo de contradição que a escritora parece querer apontar na sua obra.

Em uma das passagens do livro, tem-se o seguinte diálogo:

Acorda com o alvoroço de mulheres entrando. São as emancipadas, as intelectuais e as feministas que a burguesia de São Paulo produz.

\footnotetext{
12 Segundo Agamben, "perceber no escuro do presente essa luz que procura nos alcançar e não pode fazêlo, isso significa ser contemporâneo. Por isso os contemporâneos são raros. E por isso ser contemporâneo é, antes de tudo, uma questão de coragem: porque significa ser capaz não apenas de manter fixo o olhar no escuro da época, mas também de perceber nesse escuro uma luz que, dirigida para nós, distancia -se infinitamente de nós” (AGAMBEN, 2009,p. 65).
} 
- Acabo de sair do Gaston. Dedos maravilhosos!

- O maior coiffeur do mundo! Nem em Paris!

- Também você estava como uma fúria!

- A fazenda, querida!

- O Diário da Noite publicou minha entrevista na primeira página. Saí horrenda no cliché. Idiotas esses operários de jornal. A minha melhor frase apagada!

- Hoje é a conferência. Mas acho melhor mudar a hora das reuniões. Para podermos vir aqui!

- Será que a Lili Pinto vem com o mesmo tailleur?

- Ignóbil!

- Ela pensa que a evolução está na masculinidade da indumentária.

- Mas ela sabe se fazerinteressante.

- Pudera! Quem não arranja popularidade assim?

- Ela ainda está com o Cássio?

- E com os outros.

O barman cria cocktails ardidos. As ostras escorregam pelas gargantas bem tratadas das líderes que querem emancipar a mulher com pinga esquisita e moralidade (GALVÃO, 2006,p. 76-77).

O trecho destacado possibilita algumas considerações. Inicialmente, percebe-se a escolha pelo uso de termos estrangeiros (coiffeur, cliché, tailleur, barman, cocktails), o que, na época, era compreendido como demonstração de erudição e prestígio social. Aqui, Pagu demarca a utilização da ironia ao abordar o tipo de feminismo praticado pelas mulheres da elite de São Paulo. A passagem revela o desprezo dessas feministas pela realidade do proletariado, pois há uma referência ofensiva aos operários do jornal ("Idiotas esses operários de jornal"). A frivolidade de suas ações está representada na crítica que fazem às vestimentas e à vida amorosa de outras mulheres. A continuidade dessa cena nos oferece mais argumentos para compreender a crítica de Pagu ao moralismo hipócrita característico do feminismo burguês:

Uma matrona de gravata e grandes miçangas aparece espalhando papeis.

- Leiam. O recenseamento está pronto. Temos um grande número de mulheres que trabalham. Os pais já deixam as filhas serem professoras. E trabalhar nas secretarias... Oh! Mas o Brasil é detestável no calor. Ah! Mon Palais de Glace! 
- Se a senhora tivesse vindo antes, podería mos visitar a cientista sueca...

- Ah! Minha criada me atrasou. Com desculpas de gravidez. Tonturas.

Esfriou demais o meu banho. Também já está na rua!

O garçom alemão, alto e magro, renova os cocktails. O guardanapo claro fustiga sem querer o rosto de mlle. Dulcinéia. A língua afiada da virgenzinha absorve a cereja cristal.

- O voto para as mulheres está conseguido. É um triunfo!

- E as operárias?

- Essas são a nalfabetas. Excluídas por natureza (GALVÃO, 2006,p. 77-78).

Neste fragmento, as "feministas", ao comemorarem a "conquista" do direito das mulheres ao trabalho, demonstram desconhecimento quanto à realidade da maioria das brasileiras, que há muito trabalhavam, e em muitos casos, com uma rotina laboral extenuante. Além disso, fica evidente, mais uma vez, o descaso com a situação das mulheres operárias, que, por serem analfabetas em sua maioria, não poderiam usufruir da conquista do sufrágio. Essa exclusão da mulher proletária não parece incomodar as feministas burguesas, ao contrário, nota-se a naturalização do fato de que essas mulheres sejam excluídas dos direitos sociais conquistados e usufruídos pelas burguesas. Assim, o feminismo criticado por Pagu é aquele que consiste num movimento feito por mulheres da elite, com pautas muito particulares e que não representavam as demandas das mulheres trabalhadoras. A crítica mordaz a esse tipo de feminismo já estava presente em produções que antecederam a escrita de Parque Industrial. Por exemplo, na coluna "Mulher do Povo", sua contribuição no jornal $O$ Homem do Povo, Pagu demonstrou seu repúdio às atitudes das estud antes normalistas:

As garotas tradicionais que todo mundo gosta de ver em Sã o Paulo, risonhas, pintadas, de saias de cor e boinas vivas. [...] Com um entusiasmo de fogo e uma vibração revolucionária poderiam se quisessem, virar o Brasil e botar o Oiapoque perto do Uruguai. Mas $D$. Burguesia habita nelas e as transforma em centenas de inimigas da sinceridade. E não raro se zangam e descem do bonde, se sobe nele uma mulher do povo, escura de trabalho. [...] Ignorantes da vida e do nosso tempo![...] Acho bom vocês se modificarem, pois que no dia da reivindicação social que virá, vocês servirão de lenha para a fogueira transformadora. Se vocês, em vez de livros deturpa dos que leem, e dos beijos sifilíticos de meninotes desclassificados, voltassem um pouco 
os olhos para a avalanche revolucionária que se forma em todo o mundo e estudassem, mas estudassem de fato, para compreender o que se passa no momento, poderiam com uma convicção de verdadeiras proletárias, que não querem ser, passar uma rasteira nas velharias enferrujadas que resistem, e ficar na frente de uma mentalidade atual como autênticas pioneiras do tempo novo (GALVÃO apud CAMPOS, 2014,p. 141, itálicos nossos).

Por ter sido uma estudante da Escola Normal, Pagu conhecia bem o universo que cercava as normalistas. Sua crítica, nesse sentido, dirige-se a essas moças que, sujeitando-se aos padrões sociais da época, estavam mais preocupadas em arranjar um bom casamento do que lutar por maior liberdade para as mulheres. No livro Breve história do Feminismo (2015), Carla Cristina Garcia argumenta que a partir do século XIX, ocorre intensa incorporação das mulheres ao trabalho industrial, pois eram "mão de obra mais barata e submissa do que os homens". Garcia também aponta as diferenças crescentes entre burguesas e proletárias, pois enquanto as primeiras ficavam "enclausuradas em casa [...], símbolo de status e êxito social do homem" (GARCIA, 2015, p. 65), era cada vez maior o número de mulheres que trabalhavam nas fábricas. Esse cenário de exploração da mão de obra feminina é marcante no livro de Pagu, pelo fato de que em Parque Industrial são, sobretudo, as mulheres que sentem o peso do processo desumanizador empreendido pelas máquinas.

Nesse sentido, a construção da personagem Corina é emblemática, pois personifica as agruras sofridas pelas mulheres que acumulam opressões. Corina sofre a exploração imposta às mulheres proletárias, mas, em suas reflexões, expõe também a angústia causada pela opressão racial. Desse modo, Pagu tensiona questões que somente décadas mais tarde fariam parte das discussões propostas pelo feminismo interseccional, e "antecipa as questões dos pertencimentos identitários superpostos que algumas feministas, particularmente as feministas lésbicas e negras começam a levantar nos Estados Unidos a partir das décadas de 1970 e 1980" (ALÓS, 2010, p. 191). Um exemplo do que foi dito sobre a mencionada personagem, pode ser percebido a seguir:

Corina remenda, esforçando a vista. Por que nascera mulata? É tão bonita! Quando se pinta, então! O diabo é a cor! Por que essa diferença das outras! O 
filho era dele também. Ese saísse assim, com a sua cor de rosa seca! Por que os pretos têm filhos? (GALVÃO, 2006, p. 49, itálicos nossos).

O excerto acima ilustra a questão da discriminação racial na sociedade retratada pelo texto literário de Pagu, pois a personagem Corina demonstra consciência a respeito da segregação racial sofrida pelos negros e, especialmente, pela mulher negra. As expressões "Por que nascera mulata?", “O diabo é a cor!", “cor de rosa seca!” e "Por que os pretos têm filhos?" evidenciam a mácula do racismo presente no imaginário social representado.

Em artigo de Jules Falquet, publicado nos Cadernos de Crítica Feminista, observa-se que a autora localiza o grupo de feministas negras Combahee River Collective, surgido em Boston, no ano de 1974, como responsável pelo manifesto que afirma pela primeira vez "a inseparabilidade das opressões e, portanto, das lutas contra o racismo, o patriarcado, o capitalismo e a heterossexualidade" (FALQUET, 2012, p. 16). Esse é o contexto, segundo Falquet, em que se consolidam as discussões acerca da condição das mulheres que acumulam opressões, considerando-se, nessa análise, o recorte de gênero, raça e classe. Em outra cena do texto literário de Pagu, evidencia-se, outra vez mais, o entrelaçamento entre os tipos de opressões vivenciadas pelas mulheres pobres e negras:

Uma preta deformada aparece com o filho cinzentinho. Uma teta escorrega da boquinha fraca, murcha, sem leite. O avental encarvoado enxuga os olhinhos remelentos.

- Gente pobre não pode nem ser mãe! Me fizeram esse filho num seicomo! Tenho que dar ele pra alguém, pro coitado não morrer de fome. Se eu ficar tratando dele como é que arranjo emprego? Tenho que largar dele pra tomar conta dos filhos dos outro! Vou nanar os filhos dos rico e o meu fica aí num sei como.

Ninguém diz nada. Estão quase todas nas mesmas condições (GALVÃO, 2006,p. 81-82, itálicos nossos).

Em Parque Industrial, além das questões pertinentes às distintas realidades vividas pelas mulheres de diferentes classes sociais, Pagu também elabora um retrato perturbador acerca das violências sexuais sofridas pelo gênero feminino. Nessas cenas, 
os atos hostis são geralmente cometidos por burgueses contra vítimas pertencentes ao proletariado, ou em uma situação econômica menos favorável do que a deles. Um exemplo disso é percebido quando o burguês Alfredo mantém relação sexual com Eleonora, contra a vontade dela. Eleonora não é uma mulher proletária, mas uma jovem alienada, preocupada em arranjar um "bom” casamento. Além dela, Alfredo ainda terá uma postura abusiva com Ming, a empregada de origem chinesa que ele obriga a beijálo em troca de algumas notas a mais. Nos dois casos, Alfredo, representante da classe dominante, parecer sentir-se autorizado pela sociedade patriarcal a abusar das referidas mulheres, uma por ser sua noiva e a outra por ser sua funcionária.

Em $O$ direito à literatura, Antonio Candido afirma que a literatura pode atuar como fator de denúncia das mazelas sociais "pelo fato de focalizar as situações de restrição dos direitos, ou de negação deles, como a miséria, a servidão, a mutilação espiritual" (CANDIDO, 2004, p. 186). Pagu, embora escreva uma obra ficcional, o faz utilizando-se de elementos muito latentes da realidade social na qual está inserida. Assim, traça um percurso narrativo que expõe de maneira contumaz a situação perversa a que estão submetidos os trabalhadores no sistema capitalista, e de forma ainda mais atroz as mulheres, vítimas preferenciais, em uma sociedade economicamente desigual e marcadamente falocêntrica.

\section{Considerações finais}

Pagu é uma escritora ainda bastante negligenciada pela crítica e pelo leitor brasileiro em geral. Seu legado permaneceu incógnito por muitos anos, e ainda hoje é apenas parcialmente reconhecido. A imagem inventada a seu respeito, geralmente associada a algum estereótipo, parece anuviar a potência criadora da artista, presente em tantas e tão variadas obras. Seu primeiro romance, Parque Industrial, foi escrito já na esteira da revolução política que se avolumou em seu íntimo, especialmente a partir do encontro com Luís Carlos Prestes e com o estivador santista Herculano de Souza. Na referida obra, a autora expõe os dramas vividos pelos trabalhadores no sistema capitalista, explorados à exaustão e condenados à miséria.

Pagu queria escrever um livro que agradasse ao Partido Comunista Brasileiro, mas fez muito mais que isso. Conseguiu compor uma obra que expôs as nuances das 
mazelas causadas pela classe dominante em relação aos trabalhadores, durante o processo de industrialização de São Paulo. Assim, pode-se destacar, a partir das ideias de Sartre, que configurou uma escrita engajada, pelo fato de que almejava com seu texto evidenciar e transformar a realidade na qual estava inserida. Ela desempenhou o papel de escritora em consonância com o pensamento sartreano, para o qual "a função do escritor é fazer com que ninguém possa ignorar o mundo e considerar-se inocente diante dele. E uma vez engajado no universo da linguagem, não pode nunca mais fingir que não sabe falar" (SARTRE, 2004, p. 21-22).

Pagu logrou também desnudar a postura das alienadas feministas burguesas de sua época. A crítica direcionada por ela às mencionadas feministas expõe a indiferença destas para a causa das mulheres proletárias. Duplamente oprimida, por gênero e classe, a mulher proletária não se via representada no movimento feminista da época. Pagu soube captar essa contradição, e atacou frontalmente em seu texto literário o movimento ao traçar um retrato em que as feministas de São Paulo, mais representantes da classe dominante do que do feminismo propriamente dito, aparecem caracterizadas como fúteis, esnobes e superficiais. Ainda mais ousada na narrativa é a discussão promovida acerca das mulheres que sofrem opressão a partir de um recorte conjunto de gênero, classe e raça. Essa problematização, que incorpora o racismo presente no imaginário social, só será fortalecida dentro do movimento feminista anos mais tarde, especialmente a partir das décadas de 1960 e 1970.

\section{REFERÊNCIAS}

AGAMBEN, Giorgio. O que é contemporâneo? In: O que é contemporâneo e outros ensaios. Trad. Vinícius Nicastro Honesko. Chapecó: Editora Argos, 2009, p. 56-73.

ALÓS, Anselmo Peres. Parque Industrial: Influxos feministas no romance proletário de Patrícia Galvão. Caligrama, Belo Horizonte, v.15, n.1, p. 185-204, 2010. Disponível em: http://www.periodicos.letras.ufmg.br/index.php/caligrama/article/view/158. Acesso em: 07 Set. 2021.

ARAÚJO, Juliana Soares de; SILVA, Laísa Franzolin Malta da; PRIORI, Laura Fávero. Entre o literário social: uma leitura de Parque Industrial, de Patricia Galvão. R.E.L Revista Eletrônica de Letras, Franca, v. 7, n. 7, p. 1-40, jan.-dez. 2014. Disponível em: 
http://periodicos.unifacef.com.br/index.php/rel/article/view/846. Acesso em: 07 Set. 2021.

BOSI, Alfredo. Literatura e resistência. São Paulo: Companhia das Letras, 2002.

CAMPOS, Augusto de. Pagu: vida e obra. São Paulo: Companhia das Letras, 2014.

CANDIDO, Antonio. O direito à literatura. In: Vários escritos. $4^{a}$ ed. São Paulo: Duas Cidades, 2004, p. 169-191.

DEL PRIORE, Mary. Histórias íntimas: sexualidade e erotismo na história do Brasil. São Paulo: Editora Planeta do Brasil, 2011.

FALQUET, Jules. Romper o tabu da heterossexualidade: contribuições da lesbianidade como movimento social e teoria política. Cadernos de Crítica Feminista, Recife, v. 6, n. $5, \quad$ p. 8-31, dez. 2012. Disponível em: https://drive.google.com/file/d/16XyVfMma_G4k-dBiBcMJpd7aKQ1BP7bi/view.

Acesso em: 07 Set. 2021.

FERRAZ, Geraldo Galvão; FURLANI, Lúcia Maria Teixeira. Viva Pagu: fotobiografia de Patrícia Galvão. São Paulo: Imprensa Oficial, 2010.

FREIRE, Tereza. Dos escombros de Pagu: um recorte biográfico de Patrícia Galvão. São Paulo: Editora Senac, 2008.

FURLANI, Lucia Maria Teixeira. Pagu Patrícia Galvão: livre na imaginação, no espaço e no tempo. 5. ed. Santos: UNISANTA, 1999.

FURLANI, Lucia Maria Teixeira. Croquis de Pagu e outros momentos felizes que foram devorados unidos. São Paulo: Cortez, 2004.

GAlVÃo, Patrícia. Paixão Pagu: a autobiografia precoce de Patrícia Galvão. Rio de Janeiro: Editora Agir. 2005.

GALVÃO, Patrícia. Parque Industrial. São Paulo: Editora José Olympio, 2006.

GARCIA, Carla Cristina. Breve história do feminismo. São Paulo: Claridade, 2015.

O HOMEM DO PAU-BRASIL. Direção de Joaquim Ped ro de Andrade. Rio de Janeiro:

Vídeo Filmes, 1981. 1 DVD (107 min), NTSC, color.

RIBEIRO JUNIOR, João Carlos. Literatura e política no romance de Patrícia Galvão. Dissertação (Mestrado em Letras) - Faculdade de Filosofia, Letras e Ciências Humanas, Universidade de São Paulo, São Paulo, 2015. Disponível em: https://www.teses.usp.br/teses/disponiveis/8/8151/tde-19012017-134438/pt-br.php. Acesso em: 07 Set. 2021. 
RODRIGUES, Juliana Borges. Parque industrial de Patrícia Galvão: engajamento político e projeto estético. Dissertação (Mestrado em Letras) - Universidade Federal de Uberlândia, Uberlândia, 2009. Disponível em: https://repositorio.ufu.br/handle/123456789/11807. Acesso em: 07 Set. 2021.

SANTOS, Glauce Souza. Parque Industrial: acontecimento e descontinuidade. In: COSTA E SILVA, Natali Fabiana; CRUZ, Luana Gill da; TATIM, Janaína; PEREIRA, Marcos Paulo Torres (orgs.). Mulheres e a Literatura Brasileira. Macapá: UNIFAP, 2017, p. 198-2013.

SARTRE, Jean-Paul. Que é a Literatura? Trad. Carlos Felipe Moisés. 3. ed. São Paulo: Editora Ática, 2004. 